\title{
Pharmacognosy \\ Eco-friendly extraction and simultaneous determination of two coumarins in Justicia pectoralis (Acanthaceae)
}

\author{
Alessandra Ribeiro Sartor Lima ${ }^{1}$, Luan Augusto Cândido Lôbo ${ }^{1}$, Thaísa Lorrana da Cruz Costa ${ }^{1}$, \\ Josana de Castro Peixoto ${ }^{1}$, Leonardo Luiz Borges ${ }^{1}$, Vanessa Cristiane de Santana Amaral ${ }^{1}$ \\ \& Joelma Abadia Marciano de Paula ${ }^{1,2,3}$
}

\begin{abstract}
Justicia pectoralis (Acanthaceae) is employed in folk medicine for its analgesic, anti-inflammatory and sedative effects and to treat respiratory diseases. It is known for properties of its coumarins, 1,2-benzopyrone and umbelliferone. A green, simple, fast, and inexpensive ultrasound-assisted extractive (UAE) method for extracting umbelliferone and 1,2-benzopyrone from Justicia pectoralis was optimized. Additionally, a HPLC analytical method was developed and validated for the simultaneous determination of both coumarins. The Box-Behnken design and response surface methodology were used to evaluate the UAE process. Ethanol concentration, extraction time, plant-to-solvent ratio were the independent variables studied and the coumarin content was the dependent one. The HPLC-UV/VIS method was validated in terms of recovery, linearity, accuracy, precision and robustness, proving to be valuable for the quality control of Justicia pectoralis extract and in the development of its herbal products. Results show that the optimal UAE conditions were: ethanol concentration of $15 \%(\mathrm{w} / \mathrm{w})$, extraction time of $34 \mathrm{~min}$ and plant-to-solvent ratio of $0.1 \mathrm{~g} / \mathrm{mL}$. The predicted values of coumarin contents ( $22.16 \mu \mathrm{g} / \mathrm{mL}$ - umbelliferone and $163.86 \mu \mathrm{g} / \mathrm{mL}$ - benzopyrone) were determined under the optimal UAE conditions and proved that $\mathrm{UAE}$ is an efficient and eco-friendly extractive process for the production of aerial part extracts from Justicia pectoralis.
\end{abstract}

Key words: benzopyrone, Box-Behnken design, response surface methodology, umbelliferone.

\section{Resumo}

Justicia pectoralis (Acanthaceae) é utilizada na medicina popular como analgésico, anti-inflamatório, sedativo e no tratamento de doenças respiratórias. É conhecida pelas propriedades de suas cumarinas (1,2-benzopirona e umbeliferona). Um método ecológico, simples, rápido e barato de extração assistida por ultrassom (EAU) destas cumarinas, a partir das partes aéreas de Justicia pectoralis, foi otimizado. Adicionalmente, foi desenvolvido e validado um método analítico por CLAE para a determinação simultânea das duas cumarinas. Um modelo Box-Behnken $3^{3}$ e a metodologia de superfície de resposta foram utilizados para estimar as melhores condições da EAU. As variáveis independentes estudadas foram: concentração de etanol, tempo de extração e proporção droga/solvente. A concentração das cumarinas foi a variável dependente. O método analítico foi validado quanto aos parâmetros recuperação, linearidade, exatidão, precisão e robustez, demonstrando ser útil para o controle de qualidade do extrato de Justicia pectoralis e no desenvolvimento de seus fitoterápicos. Os resultados mostraram que as melhores condições da EAU foram: concentração de etanol de $15 \%(\mathrm{p} / \mathrm{p})$, tempo de extração de 34 min e proporção droga/solvente de $0,1 \mathrm{~g} / \mathrm{mL}$. Os valores previstos pelo modelo para as concentrações de umbeliferona $(22,16 \mu \mathrm{g} / \mathrm{mL})$ e benzopirona $(163,86 \mu \mathrm{g} / \mathrm{mL})$ foram determinados nas condições otimizadas e provaram que a EAU é um processo extrativo eficiente e ecologicamente correto para a produção de extratos a partir das partes aéreas da Justicia pectoralis.

Palavras-chave: benzopirona, modelo Box-Behnken, metodologia de superfície de resposta, umbeliferona.

\footnotetext{
'State University of Goiás, Anápolis Campus of Exact and Technological Sciences, BR 153, Fazenda Barreiro do Meio, 75132-903, Anápolis, GO, Brazil.

${ }^{2}$ ORCID: $<$ https://orcid.org/0000-0003-0737-2600>

${ }^{3}$ Author for correspondence: joelma.paula@ueg.br
} 


\section{Introduction}

Justicia pectoralis Jacq. (Acanthaceae) is a herb native to Latin America that has been widely researched for its medicinal properties such as analgesic, anti-inflammatory, anti-asthmatic, antioxidant, and sedative effects (Lino et al. 1997; Parra et al. 2001; Cheng et al. 2004; Han et al. 2005; Kostova 2005; Chanfrau et al. 2008; Venâncio et al. 2011; Arcanjo et al. 2012; Leal et al. 2017). The main active compounds are the coumarins 1,2-benzopyrone and umbelliferone (Fig.1) found in higher concentration in its aerial parts (Angonese et al. 1992; Barros et al. 1997; Oliveira \& Andrade 2000; Govín et al. 2003). Preclinical studies showed an anxiolytic-like effect of $J$. pectoralis extracts (Venâncio et al. 2011). Dry extract has been used as an active pharmaceutical ingredient in liquid and tablet formulation, but there are still practical limitations for its clinical application, such as the efficiency of extraction/ drying methods and the obtainability of sensitive and accessible analytical methods for a quality control routine (Fonseca et al. 2010; Arteaga et al. 2011; Martín-Viaña et al. 2011; Chanfrau \& Rodríguez 2014; Chanfrau et al. 2015).

Different HPLC analytical methods have been proposed and used in the quantification of coumarins from $J$. pectoralis (Chanfrau et al. 2008; Fonseca et al. 2010), but many have been performed from complex extractive processes that make the method more difficult, with high and costly solvent consumption. In addition, there are no validated methods proposed in the literature to quantify the two markers simultaneously. The efficiency and accuracy of an analytical method for evaluating bioproducts depends on the extraction method.

Methods by solid liquid extraction with water by reflux process or with hydroalcoholic solution

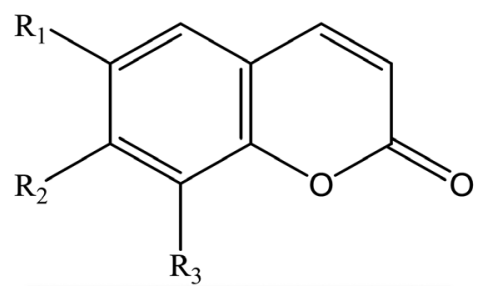

$\mathrm{R} 1=\mathrm{R} 2=\mathrm{R} 3=\mathrm{H}:$ 1,2-benzopyrone (coumarin) $\mathrm{R} 1=\mathrm{R} 3=\mathrm{H}, \mathrm{R} 2=\mathrm{OH}$ : umbelliferone (7-hidroxycoumarin)

Figure 1 - The main metabolites present in J. pectoralis. by percolation extraction are used for extraction involving the aerial parts of J. pectoralis (Lino et al. 1997; Chanfrau \& Rodríguez 2014; Locklear et al. 2010; Chanfrau et al. 2013; Cameron et al. 2015). These methods have some limitations, such as high energy consumption, long extraction time (up to $4 \mathrm{~h}$ for Soxhlet or days for percolation extractions) and the low yield of the process. However, faster extraction methods, such as ultrasound-assisted extraction (UAE), which enable higher levels of the markers of $J$. pectoralis to be obtained in a short time and with reduced solvent consumption, are not described in the literature. This method is based on the mechanical and cavitation forces caused by sound waves, and it leads to the reduction of particle size, breakdown of the plant cell wall and increased mass transfer through the membrane (Cárcel et al. 2012; Wang et al. 2013; Paz et al. 2015; Zhou et al. 2017), making it a cheap, fast, green and efficient alternative compared to conventional extraction techniques.

The objective of this study was to achieve the optimal eco-friendly extraction process for 1,2-benzopyrone and umbelliferone from the aerial parts of $J$. pectoralis through ultrasound-assisted extraction. Additionally, was validated a HPLCUV/VIS method for simultaneous identification and quantification of 1,2-benzopyrone and umbelliferone in these extracts.

\section{Materials and Methods}

\section{Plant material}

The aerial parts (branches with leaves and flowers) of $J$. pectoralis were collected in the herb garden of the Goiânia Botanical Garden (latitude $16^{\circ} 19^{\prime} 36^{\prime \prime S}$, longitude 48 57'10' W, altitude 1,017 $\mathrm{m})$, located in Goiânia city, and at the Universidade Estadual de Goiás (UEG) (latitude 16¹7'13.8'S, longitude $48^{\circ} 57^{\prime} 22.7^{\prime \prime} \mathrm{W}$, altitude 1,074 m), Anápolis city, both in Goiás state, Brazil. Voucher specimens are deposited in the Herbarium of the UEG (HUEG10764). The samples ( $8 \mathrm{~kg}$ fresh plant) were dried at $40{ }^{\circ} \mathrm{C}$ for $24 \mathrm{~h}$ in an oven with circulating air and crushed in a knife mill. The loss during drying was of $8.76 \% \pm 0.18$ and the average diameter of powder particles was 0.425 mm (Brazil 2010).

\section{General procedures}

An ultrasonic device (USC 2800A, $40 \mathrm{kHz}$, 154W, Unique ${ }^{\circledR}$ ) equipped with a digital timer and a temperature controller was used for the ultrasoundassisted extractions (UAE). 
A Varian HPLC ProStar with separation modules, 240 ternary pump, 310 automatic injector and 20599 UV detector, and software Star (Chromatography Workstation) were used. Column Ascentis ${ }^{\circledR}$ Supelco Analytical C18 (250 mm $\times 4.6$ $\mathrm{mm}, 5 \mu \mathrm{m})$. RC -Vliesverstärkt membrane (0.45 $\mu \mathrm{m}$, Sartorius Biolab Products). The analytical standards were 1,2-benzopyrone and umbelliferone (Sigma Aldrich, St. Louis, MO, USA). The samples and analytical standard solutions were previously filtered through a $0.45 \mu \mathrm{m}$ O-45/15 MS membrane (Macherey-Nagel).

\section{Method validation}

The HPLC-UV/VIS chromatographic systems tested before validation method and the HPLC-UV-VIS system chosen includes an isocratic mobile phase with methanol/water (40:60), wavelength of $323 \mathrm{~nm}$, and flow rate of $1 \mathrm{~mL} / \mathrm{min}$. The sample was prepared through ethanol extract obtained by UAE (ethanol - 20\% (w/w), plant-tosolvent ratio of $0.066 \mathrm{~g} / \mathrm{mL}$ and extraction time of 20 minutes). The prerogatives of the International Conference on the Harmonization (ICH) of Technical Requirements for the Registration of Pharmaceuticals for Human Use (ICH 2005) and Brazilian legislation (Brazil 2017) were followed for method validation.

Linearity: the calibration curves for linearity were determined by analysis at six concentration levels of the 1,2-benzopyrone standard (512.0, 409.6, 286.7, 172.0, 103.2 and $41.3 \mu \mathrm{g} / \mathrm{mL}$ ) and six concentration levels of the umbelliferone standard $(29.7,23.7,16.6,9.9,5.9$ and $2.4 \mu \mathrm{g} / \mathrm{mL})$ in mobile phase. The calibration curve was fitted by linear regression from the correlation between the peak areas and the concentration of the standards, with analysis of linear regression coefficients (R) and analysis of variance (ANOVA). The average calibration curve and the resulting equation of the standard linear regression were used to quantify coumarins in $J$. pectoralis extracts.

Limit of detection (LOD) and limit of quantification (LOQ): these were calculated according to Eqs. 1 and 2, based on the standard deviation $\left(\mathrm{SD}_{\mathrm{b}}\right)$ of the intercept with the $\mathrm{y}$-axis and the slope of the calibration curve (S), obtained from three equations of the linearity calibration curves.

$$
\begin{aligned}
& L O D=\frac{S D b \times 3}{S} \\
& L O Q=\frac{S D b \times 10}{S}
\end{aligned}
$$

Selectivity: the coelution of analytes and other extract components was evaluated comparing the chromatograms of a blank (methanol/water, 40:60), sample solution and standards; and comparing UV absorption spectra of the analytes in the samples and standards.

Precision: the method's precision was considered at the levels of repeatability and intermediate precision. The repeatability (intraday precision) was evaluated by analyzing six injections of the test concentration and the intermediate precision (inter-day precision) was evaluated by this same process, performed by two different analysts on different days. In both tests, the relative standard deviation (RSD) was used as the evaluation criterion, in agreement with $\mathrm{ICH}$ recommendations (ICH 2005).

Accuracy: 1,2-benzopyrone and umbelliferone reference standards were accurately weighed, and the sample solutions were prepared at three concentration levels corresponding to 80,100 and $120 \%$ of the standard concentration in the linear range, with and without the addition of a known amount of the 1,2-benzopyrone standard $(60.7 \mu \mathrm{g} /$ $\mathrm{mL})$ and umbelliferone standard $(17.6 \mu \mathrm{g} / \mathrm{mL})$. At each level, samples were prepared in triplicate and the recovery percentage was determined.

Robustness: this was evaluated by analyzing the results of the coumarin content obtained from the changed in the column lot, injection volume and the flow. The results were evaluated by RSD calculation, with samples in triplicate.

\section{Extract preparation}

The extraction conditions for optimization of the UAE process for coumarins from $J$. pectoralis included ethanol as a green solvent (Prat et al. 2016), and the experiments were set out in a BoxBehnken design. The variables studied, which affect extraction efficiency, were chosen from literature data (Chanfrau et al. 2008; Wang et al. 2013) and our previous experiments (data not showed), which indicated increased coumarin extractions with low ethanol concentrations. The three variables investigated at three levels $\left(3^{3}\right)$ were: ethanol concentrations of 15,30 , and $45 \%$ (w/w, $x_{1}$ ); extraction times of 20, 40, and $60 \mathrm{~min}$ $\left(x_{2}\right)$, and plant-to-solvent ratios of $0.10,0.07$, and $0.05 \mathrm{~g} / \mathrm{mL}\left(x_{3}\right)$. The response variables were the 1,2-benzopyrone and umbelliferone contents achieved by HPLC-UV/Vis validated method. The complete process was carried out in randomly arranged order, consisting of 15 combinations, 
including 3 replicates at the central point. Results were adjusted to a second-order polynomial regression model according to the following equation (Eq. 3).

$$
y=\beta_{0}+\sum_{i=1}^{k} \beta_{i} x_{i}+\sum_{i=1}^{k} \beta_{i i} x_{i}^{2}+\sum \sum \beta_{i j} x_{i} x_{j}
$$

Where: $\mathrm{y}$ is the predicted response quantified by an extraction recovery; $x_{i}$ and $x_{j}$ represent the levels of the independent variables; $\beta_{0}$ is the model constant; $\beta_{i}$ is the linear coefficient; $\beta_{i i}$ is the quadratic coefficient; and $\beta_{i j}$ is the cross-product coefficient (Said \& Amin 2015).

Response surface methodology (RSM) was built to express the response effects of the three independent variables on the 1,2-benzopyrone and umbelliferone content, to verify the predictive capability of the model and to set the optimal extraction conditions within the evaluated intervals. Statistica software (version 12.0) was used to analyze the experimental results, where two-way linear and quadratic interactions were included, considering only the factors with $p<0.05$ as significant.

Coumarin contents achieved by the optimized UAE conditions were compared by ones achieved by percolation process. To obtain the percolated extract, $500 \mathrm{~g}$ of plant material were exhausting percolated in approximately $2.5 \mathrm{~L}$ ethanol $20 \%$ $(\mathrm{w} / \mathrm{w})$ and concentrated in a Buchi ${ }^{\circledR}$ rotary evaporator (R-220SE model) under vacuum (40 $\left.{ }^{\circ} \mathrm{C}\right)$, until solid content of $2.5 \%(\mathrm{w} / \mathrm{w})$.

\section{Results and Discussion}

Method validation

The UV/VIS scanning spectrum (200-800 $\mathrm{nm}$ ) of 1,2-benzopyrone and umbelliferone reference standards showed $323 \mathrm{~nm}$ as the best wavelength for the analysis of both coumarins.

The comparison of the concentrated liquid extract (CLE), coumarin standards (CS), and diluent chromatographic profiles (Fig. a,b) confirmed the spectral similarity of coumarin peaks at CLE and CS, as well the selectivity of the method. Peaks of interfering substances in the blank were not observed at the retention time of coumarins (Fig. 2c). Different conditions for the mobile phase and flow were tested according to the literature and the best condition chosen for method validation was 40/60 methanol/water for mobile phase and $1 \mathrm{ml} / \mathrm{min}$ for flow. This method showed system suitability results in accordance with ICH and Brazilian regulations (ICH 2005; Brazil 2017) (Tab. 1).

The method was linear in the analyzed interval and the representative linear equation was $\mathrm{y}=22473 \mathrm{x}-13376\left(\mathrm{~N}=6 ; \mathrm{R}^{2}=0.9999 ; \mathrm{RSD}\right.$ $=1.00 \%$ ) for 1,2-benzopyrone and $\mathrm{y}=36778 \mathrm{x}$ - $14097\left(\mathrm{~N}=6, \mathrm{R}^{2}=0.9999, \mathrm{RSD}=1.00 \%\right)$ for umbelliferone. The slope of the 1,2-benzopyrone and umbelliferone calibration curves showed a relative standard deviation $\left(\mathrm{RSD}^{\circ}\right)$ ) of $1.00 \%$. This value is within the limits set by ICH and Brazilian regulations (ICH 2005; Brazil 2017), which should not exceed 5\%. However, a correlation coefficient value $\left(\mathrm{R}^{2}\right)$ close to unit is not enough to confirm the linear correlation; thus, it is necessary to apply a lack-of-fit test to evaluate the variance of the residual values (Hadad et al. 2009). In the ANOVA evaluation for the 1,2-benzopyrone and umbelliferone linearity, the calculated $F$ value for the lack-of-fit was smaller than the tabulated $F$ value, with a confidence level of $95 \%(p=0.05)$, not showing lack-of-fit for linear regression (Tabs. $2 ; 3)$.

The limits of detection (LOD) in the indicated experimental conditions were $5.81 \mu \mathrm{g} / \mathrm{mL}(0.00581$ $\mathrm{mg} / \mathrm{mL}$ ) for 1,2-benzopyrone and $0.35 \mu \mathrm{g} / \mathrm{mL}$ $(0.00035 \mathrm{mg} / \mathrm{mL})$ for umbelliferone. The limits of quantification (LOQ) under the indicated experimental conditions were $19.37 \mu \mathrm{g} / \mathrm{mL}$ $(0.01937 \mathrm{mg} / \mathrm{mL})$ for 1,2-benzopyrone and 1.799 $\mu \mathrm{g} / \mathrm{mL}(0.001799 \mathrm{mg} / \mathrm{mL})$ for umbelliferone.

In the intra-day precision analysis, on day 1 (analyst 1) the RSD results were $2.77 \%$ for 1,2-benzopyrone and 3.61\% for umbelliferone; on day 2 (analyst 2 ) the RSD results were 5.91\% for 1,2-benzopyrone and $4.65 \%$ for umbelliferone. In the inter-day precision analysis, the RSDs were $5.35 \%$ for 1,2-benzopyrone and $6.55 \%$ for umbelliferone. Table 4 shows the results obtained for the method's precision, at the levels of repeatability and intermediate precision. In both tests, the RSD for markers was carried out with six determinations.

Table 5 data show the results of accuracy by the recovery test. The recovery ranged from $86.36 \%$ to $97.81 \%$ for 1,2-benzopyrone, with an average of $94.07 \%(\mathrm{RSD}=3.65 \%)$, and from $92.44 \%$ to $99.48 \%$ for umbelliferone, with an average of $94.93 \%(\mathrm{RSD}=4.81 \%)$. The recovery test measures the amount of the substance of interest present or added in the analytical portion of the test material that is extracted and capable of being measured (Thompson et al. 1999). The 

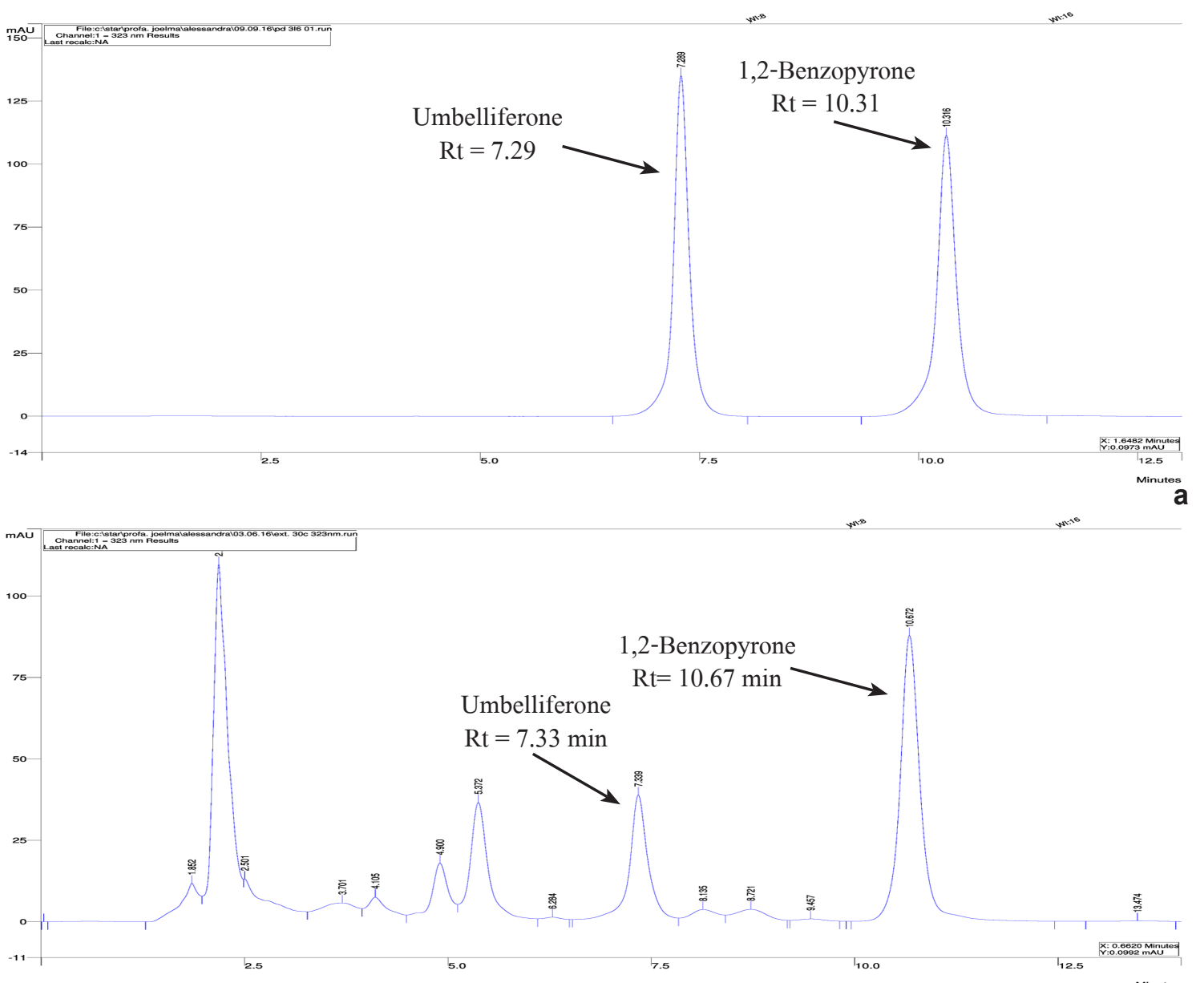

Figure 2 - a-b. HPLC-UV chromatographic profiles - a. coumarin standards; b. concentrated liquid extract from Justicia pectoralis aerial parts. Chromatographic conditions: C18 column $(250 \times 4.6 \mathrm{~mm}, 5 \mu \mathrm{m})$; mobile phase methanol/water (40:60); flow rate of $1.0 \mathrm{ml} / \mathrm{min}, \lambda=323 \mathrm{~nm}$; injection volume of $20 \mu \mathrm{L}$.

acceptable intervals may range from 50 to $120 \%$ with an accuracy of $\pm 15 \%$ (Ribani et al. 2004).

The statistical analysis of robustness confirmed no significant difference between the results obtained in the different analytical conditions for the method. The RSDs for coumarin concentrations were $6.74 \%$ for 1,2- benzopyrone and $6.60 \%$ for umbelliferone under the flow changed at $0.1 \mathrm{~mL} / \mathrm{min}$.; when the injection volume was changed at $1 \mu \mathrm{L}$ the RSDs were $4.31 \%$ for 1,2- benzopyrone and $4.74 \%$ for umbelliferone, and when column lot was changed the results were $2.06 \%$ for 1,2 - benzopyrone and $2.43 \%$ for umbelliferone. These results showed the robustness in accordance with recommends of guidelines for registering herbal medicines and for notifying traditional herbal products (Brazil 2014). These guidelines recommend defined that admissible the maximum for RSD values in the analytical validation should be defined by the kind of method, matrix complexity, analyte concentration and purpose of the method, but the RSD should not exceed $15 \%$. The demonstration of robustness is critical in the transference of the analytical process to other laboratories (Ribani et al. 2004).

The literature methods were not so able to quantify both important coumarins in the same analysis, determining only 1,2-benzopyrone content (Chanfrau et al. 2008), or were not so simple, cheaper and useful for quality control application it necessary a more complex mobile phase in a gradient system and using a high flow (Fonseca $e t$ al. 2010). The HPLC-UV/VIS analytical method developed for coumarin quantification met the 
Table 1 - Mean $( \pm \mathrm{SD})$ of the system's suitability parameters for the validated chromatographic method, obtained from six coumarin determinations in the ethanol extract of $J$. pectoralis.

\begin{tabular}{|c|c|c|c|}
\hline \multicolumn{4}{|c|}{ System suitability } \\
\hline & Tailing factor (TF) & Resolution (Rs) & Theoretical plates $(\mathrm{N})$ \\
\hline $\begin{array}{l}\text { Sample } \\
\text { umbelliferone peak }\end{array}$ & 0 & $2.97( \pm 0.05)$ & $5157.8( \pm 259.37)$ \\
\hline $\begin{array}{l}\text { Sample } \\
\text { 1,2-benzopyrone peak }\end{array}$ & $1.03( \pm 0.01)$ & $2.16( \pm 0.05)$ & $6220( \pm 241.65)$ \\
\hline Literature recommendations (ICH 2005) & $\leq 2.00$ & $\geq 2.00$ & $>2000.00$ \\
\hline
\end{tabular}

validation criteria established in the ICH guidelines and Brazilian regulations; the method demonstrated to be fast, not complex and able to determine the two most important compounds in aerial parts of $J$. pectoralis, simultaneously and with individual evaluation.

\section{Evaluation of extraction parameters}

for coumarins content

The present study was performed to obtain an optimized extraction method of coumarins (1,2-benzpyrone/umbelliferone) in ethanol solution from the aerial parts of Justicia pectoralis. The ethanol was chosen because it is an agro-solvent with chemical and physical stability, low volatility, ease of use, and with the possibility of reuse. Promoting this way, safety and environmental protection, and process sustainability (Prat et al. 2016; Chemat et al. 2019). These characteristics define ethanol as a green solvent more suitable for use in friendly processes than methanol, a toxic solvent commonly used in extractive process. The use reduction of hazardous solvents is also one of the priorities of international environmental policies and legislations for 20102050 periods (Bubalo et al. 2018).

Two extraction methods were used, extraction percolation and ultrasound assisted extraction, both with the ethanol solution as the solvent. This option was defined from previous tests that indicated better solubility of umbelliferone in low concentration ethanol solutions. This option was defined from previous tests that indicated better solubility of umbelliferone, in addition to the low toxicity of ethanol, which is the only solvent other than water allowed in medicinal plant extractions by national and international regulatory agencies.

The coumarin content of extracts from 15 experiments generated by the Box-Behnken design and multiple linear regression analysis using the quadratic polynomial model are showed in Tables 6 to 8 . The results for 1,2-benzopyrone contents were demonstrated to be significant ( $p=0.000084)$,

Table 2 - ANOVA data for umbelliferone and 1,2-benzopyrone linearity.

\begin{tabular}{lccccc}
\hline & $\boldsymbol{D F}$ & $\boldsymbol{S S}$ & $\boldsymbol{M S}$ & $\boldsymbol{F}$ & $\boldsymbol{F}$ tab \\
\hline Umbelliferone & 1 & $2.27107 \mathrm{E}+12$ & $2.27107 \mathrm{E}+12$ & 30942.13704 & $7.65878 \mathrm{E}-22$ \\
Residual & 16 & 1026008626 & 64125539.1 & & \\
Lack-of- Fit & 4 & 145239380.3 & 36309845.07 & 0.494701811 & 0.74009069 \\
Pure error & 12 & 880769245.3 & 73397437.11 & $\boldsymbol{F}$ tab \\
\hline & $\boldsymbol{D F}$ & $\boldsymbol{S S}$ & $\boldsymbol{M S}$ & 221259.0286 & $5.73934 \mathrm{E}-27$ \\
1,2-Benzopyrone & 1 & $2.52336 \mathrm{E}+14$ & $2.52336 \mathrm{E}+14$ & & 0.055327445 \\
Residual & 16 & 28011982530 & 1750748908 & 3.140537599 & \\
Lack-of- Fit & 4 & 14326544369 & 3581636092 & & \\
Pure error & 12 & 13685438161 & 1140453180 & & \\
\hline
\end{tabular}

$\mathrm{DF}=$ Degrees of freedom; $\mathrm{SS}=$ Sum of Squares $\mathrm{MS}=$ Mean Squares $; \mathrm{F}=$ calculated $\mathrm{F}$ value $; \mathrm{Ftab}=$ tabulated $\mathrm{F}$ value . 
Table 3 - Summary of the calibration curve parameters of umbelliferone and 1,2-benzopyrone.

\begin{tabular}{ccc}
\hline & Umbelliferone & 1,2-Benzopyrone \\
\hline Linear range $(\mu \mathrm{g} / \mathrm{mL})$ & $29.7-2.4$ & $512.0-41.3$ \\
Limit of detection $(\mu \mathrm{g} / \mathrm{mL})$ & 0.3539 & 5.8110 \\
Limit of quantification $(\mu \mathrm{g} / \mathrm{mL})$ & 1.1799 & 19.3700 \\
\hline Linear regression data* & & 6 \\
\hline $\mathrm{N}$ & 6 & 22473 \\
Slope $(\mathrm{a})$ & 36778 & 125.19 \\
\hline Standard deviation of slope & 210.01 & 0.55 \\
Relative standard deviation of slope $(\%)$ & 0.57 & 133760 \\
y-axis intercept $(\mathrm{b})$ & 14097 & 1.0000 \\
\hline
\end{tabular}

$* \mathrm{y}=\mathrm{ax}+\mathrm{b}$, where $\mathrm{x}$ is the compound concentration and $\mathrm{y}$ is the peak area.

and $\mathrm{R}^{2}$ and $\mathrm{R}^{2}$ adj values were 0.997 and 0.99 , respectively. The results for umbelliferone contents were significant too $(p=0.000011)$, and $\mathrm{R}^{2}$ and $\mathrm{R}^{2}$ adj values were 0.999 and 0.99 , respectively. These confirm the model's suitability. The lack-of-fit was not significant $(p>0.05)$, which indicates the suitability of the model to accurately predict the variation. The data from the analysis of variance (ANOVA) for the quadratic polynomial regression model for umbelliferone content showed a significant primary linear effect $(\mathrm{p}<0.05)$ of ethanol concentration $\left(x_{1}\right)$, time $\left(x_{2}\right)$ and plant-to-solvent ratio $\left(x_{3}\right)$ and a significant primary quadratic effect $(\mathrm{p}<0.05)$ of ethanol concentration $\left(x_{1}^{2}\right)$ and of plant-to-solvent ratio $\left(x_{3}^{2}\right)$ on the umbelliferone content. The secondorder interactions were significant $(\mathrm{p}<0.1)$ for ethanol concentration $\left(x_{1}\right) / \operatorname{time}\left(x_{2}^{2}\right)$, ethanol concentration $\left(x_{1}^{2}\right) /$ time $\left(x_{2}\right)$, ethanol concentration $\left(x_{1}\right) /$ plant-to-solvent ratio $\left(x_{3}\right)$, ethanol concentration $\left(x_{1}^{2}\right) /$ plant-to-solvent $\operatorname{ratio}\left(x_{3}\right)$ and time $\left(x_{2}\right) /$ plant-to-solvent $\operatorname{ratio}\left(x_{3}\right)$. The data for 1,2-benzopyrone content also showed a significant primary linear effect $(p<0.05)$ of the plantto-solvent ratio $\left(x_{3}\right)$ on the 1,2-benzopyrone content. The second order interactions were significant $(p<$
$0.05)$ for ethanol concentration $\left(x_{1}\right) / \operatorname{time}\left(x_{2}\right)$, ethanol concentration $\left(x_{1}\right)$ /plant-to-solvent $\operatorname{ratio}\left(x_{3}^{2}\right)$ and time $\left(x_{2}\right) /$ plant-to-solvent ratio $\left(x_{3}^{2}\right)$.

Figure 3a-c present the response surface and contour plots for the influences of UAE parameters on coumarin content. As shown in Figure 3a-b, the maximum extraction of umbelliferone was obtained in plant-to-solvent $\left(x_{3}\right)$ range between 0.07 and 0.1 $\mathrm{g} \mathrm{mL}^{-1}$, at any of the ethanol concentrations $\left(x_{1}\right)$ and times $\left(x_{2}\right)$, guiding that the maximum extraction point is outside the experimental limit, but due to high intumescence of the plant material this test is not viable.

In Figure 3c, the maximum extraction of umbelliferone was obtained in low ethanol concentration $\left(x_{1}\right)$ at any of the times $\left(x_{2}\right)$. Umbelliferone is slightly soluble in water, and is freely soluble in ethanol, chloroform, acetic acid and dilute alkaline solution (Macrae \& Towers 1984; Vriest et al. 1988), which may explain the efficiency of its extraction in ethanol solution. Hydroethanolic solutions are widely used in extractive processes precisely because of their extraction efficiency and low toxicity compared to other organic solvents.

Table 4 - Precision studies for coumarin quantification in the concentrated liquid extract from Justicia pectoralis aerial parts.

\begin{tabular}{lccccc}
\hline Coumarins & $\begin{array}{c}\text { \% Assay } \\
\text { (Day-1, Analyst-1) }\end{array}$ & $\begin{array}{c}\text { \% RSD of Assay } \\
(\mathbf{N}=\mathbf{6})\end{array}$ & $\begin{array}{c}\text { \% Assay (Day-2, } \\
\text { Analyst-2) }\end{array}$ & $\begin{array}{c}\text { \% RSD of Assay } \\
\text { (N = 6) }\end{array}$ & \% RSD Inter -day \\
\hline 1,2-Benzopyrone & 0.778 & 2.77 & 0.732 & 5.91 & 5.35 \\
Umbelliferone & 0.096 & 3.61 & 0.087 & 4.65 & 6.55 \\
\hline
\end{tabular}


Table 5 - Accuracy studies for 1,2-Benzopyrone and Umbelliferone quantification in a concentrated liquid extract from Justicia pectoralis aerial parts.

\begin{tabular}{lccccc}
\hline Coumarins & Levels (\%) & Amount recovered $(\mathbf{m g} / \mathbf{m L})$ & \% Recovery & Mean \% recovery & \% RSD \\
\hline 1,2-Benzopyrone & Low & 16.00 & 95.46 & & \\
& Medium & 20.00 & 95.70 & 94.07 & 3.65 \\
& High & 24.00 & 91.06 & & \\
Umbelliferone & Low & 16.00 & 99.30 & & \\
& Medium & 20.00 & 95.57 & 94.93 & 4.81 \\
& High & 24.00 & 89.92 & & \\
\hline
\end{tabular}

Figure 4a shows that the maximum extraction of 1,2-benzopyrone was obtained in the low ethanol concentration $\left(x_{1}\right)$ at low $\operatorname{times}\left(x_{2}\right)$ of the experiment. This effect may be related with the coumarin degradation when the sample was kept longer in the ultrasound bath. Studies about ultrasonically assisted extraction have shown that extraction rates do not increase significantly with increasing extraction times, often causing degradation of various metabolites (Vinatoru 2001;
Chanfrau et al. 2016). These results indicate the need of the further studies to evaluate possible degradation products can take place during the process.

Evidencing the quadratic effect identified by the model, a lower concentration of ethanol decreased 1,2-benzopyrone extraction when the time of extraction was more than $35 \mathrm{~min}$.

Figure 4b-c shows that the greatest 1,2-benzopyrone contents were observed at

Table 6 - Experimental design (Box-Behnken $3^{3}$ ) used to analyze the coumarin content (dependent variable) of UAE of $J$. pectoralis, and the process variables $X_{1}, X_{2}$, and $X_{3}$.

\begin{tabular}{|c|c|c|c|c|c|}
\hline Run number & $\begin{array}{c}X_{1} \\
(\%)\end{array}$ & $\begin{array}{c}X_{2} \\
(\min )\end{array}$ & $\begin{array}{c}X_{3} \\
(\mathrm{~g} / \mathrm{mL})\end{array}$ & $\begin{array}{c}\text { Umbelliferone } \\
(\mu \mathrm{g} / \mathrm{mL})\end{array}$ & $\begin{array}{c}\text { 1,2-Benzopyrone } \\
(\mu \mathrm{g} / \mathrm{mL})\end{array}$ \\
\hline 1 & 15 & 20 & 0.07 & 14.00 & 166.78 \\
\hline 2 & 45 & 20 & 0.07 & 10.41 & 105.63 \\
\hline 3 & 15 & 60 & 0.07 & 16.81 & 109.34 \\
\hline 4 & 45 & 60 & 0.07 & 12.34 & 118.24 \\
\hline 5 & 15 & 40 & 0.10 & 22.58 & 161.04 \\
\hline 6 & 45 & 40 & 0.10 & 17.95 & 171.47 \\
\hline 7 & 15 & 40 & 0.05 & 11.41 & 84.85 \\
\hline 8 & 45 & 40 & 0.05 & 9.81 & 86.46 \\
\hline 9 & 30 & 20 & 0.10 & 17.38 & 150.69 \\
\hline 10 & 30 & 60 & 0.10 & 21.62 & 163.11 \\
\hline 11 & 30 & 20 & 0.05 & 7.81 & 71.51 \\
\hline 12 & 30 & 60 & 0.05 & 9.94 & 85.52 \\
\hline 13 & 30 & 40 & 0.07 & 12.34 & 111.61 \\
\hline 14 & 30 & 40 & 0.07 & 12.59 & 110.67 \\
\hline 15 & 30 & 40 & 0.07 & 12.47 & 106.48 \\
\hline
\end{tabular}

$X_{1}=$ ethanol; $X_{2}=$ time; $X_{3}=$ plant-to-solvent ratio. 
Table 7 - Analysis of variance (ANOVA) for the quadratic polynomial regression model for umbelliferone content.

\begin{tabular}{cccccc}
\hline Factor & $\begin{array}{c}\text { Sum } \\
\text { of squares }\end{array}$ & $\begin{array}{c}\text { Degrees } \\
\text { of freedom }\end{array}$ & $\begin{array}{c}\text { Mean } \\
\text { squares }\end{array}$ & F value & $p$ \\
\hline$X_{1}$ & 24.9761 & 1 & 24.9761 & 1597.62 & $0.000625^{*}$ \\
$X_{2}$ & 12.5611 & 1 & 12.5611 & 803.48 & $0.001242^{*}$ \\
$X_{3}$ & 179.2208 & 1 & 179.2208 & 11464.02 & $0.000087^{*}$ \\
$X_{1}^{2}$ & 3.1250 & 1 & 3.1250 & 199.89 & $0.004965^{*}$ \\
$X_{3}^{2}$ & 2.1819 & 1 & 2.1819 & 139.57 & $0.007089^{*}$ \\
$X_{1} X_{2}^{2}$ & 0.4186 & 1 & 0.4186 & 26.78 & $0.035376^{*}$ \\
$X_{1}^{2} x_{2}$ & 0.3321 & 1 & 0.3321 & 21.24 & $0.043990^{*}$ \\
$X_{1}^{2} X_{2}^{2}$ & 0.0985 & 1 & 0.0985 & 6.30 & 0.128760 \\
$X_{1} X_{3}$ & 2.2952 & 1 & 2.2952 & 146.82 & $0.006742^{*}$ \\
$X_{1}^{2} X_{3}$ & 0.4705 & 1 & 0.4705 & 30.09 & $0.031661^{*}$ \\
$X_{2} X_{3}$ & 1.1130 & 1 & 1.1130 & 71.20 & $0.013757^{*}$ \\
Lack-of-fit & 0.193 & 1 & 0.1936 & 12.38 & $0.072124^{*}$ \\
Pure error & 0.031 & 2 & 0.0156 & & \\
\hline Sum of squares total & 268.3766 & 14 & & & \\
\hline
\end{tabular}

$X_{I}=$ ethanol; $X_{2}=$ time; $X_{3}=$ plant-to-solvent ratio * $\mathrm{p}<0.05$.

Table 8 - Analysis of variance (ANOVA) for the quadratic polynomial regression model for 1,2-benzopyrone content.

\begin{tabular}{cccccc}
\hline Factor & $\begin{array}{c}\text { Sum } \\
\text { of squares }\end{array}$ & $\begin{array}{c}\text { Degrees of } \\
\text { freedom }\end{array}$ & $\begin{array}{c}\text { Mean } \\
\text { squares }\end{array}$ & F value & $\boldsymbol{p}$ \\
\hline$X_{1}$ & 39.68 & 1 & 39.68 & 5.319 & 0.147508 \\
$X_{1}^{2}$ & 1.65 & 1 & 1.65 & 0.221 & 0.684861 \\
$X_{2}$ & 3.22 & 1 & 3.22 & 0.432 & 0.578452 \\
$X_{3}$ & 11268.90 & 1 & 11268.90 & 1510.692 & $0.000661^{*}$ \\
$X_{1} X_{2}$ & 1226.75 & 1 & 1226.75 & 164.456 & $0.006026^{*}$ \\
$X_{1} X_{3}^{2}$ & 516.65 & 1 & 516.65 & 69.261 & $0.014133^{*}$ \\
$X_{1}^{2} X_{3}^{2}$ & 1.83 & 1 & 1.83 & 0.246 & 0.669163 \\
$X_{2} X_{3}^{2}$ & 634.75 & 1 & 634.75 & 85.093 & $0.011549^{*}$ \\
$X_{2}^{2} X_{3}$ & 2.45 & 1 & 2.45 & 0.329 & 0.624220 \\
$X_{2}^{2} X_{3}^{2}$ & 38.99 & 1 & 38.99 & 5.227 & 0.149562 \\
Lack-of-fit & 20.08 & 2 & 10.04 & 1.346 & 0.426266 \\
Pure error & 14.92 & 2 & 7.46 & & \\
Sum of squares total & 15885.45 & 14 & & & \\
\hline
\end{tabular}

$X_{1}=$ ethanol; $X_{2}=$ time; $X_{3}=$ plant-to-solvent ratio $* \mathrm{p}<0.05$. 

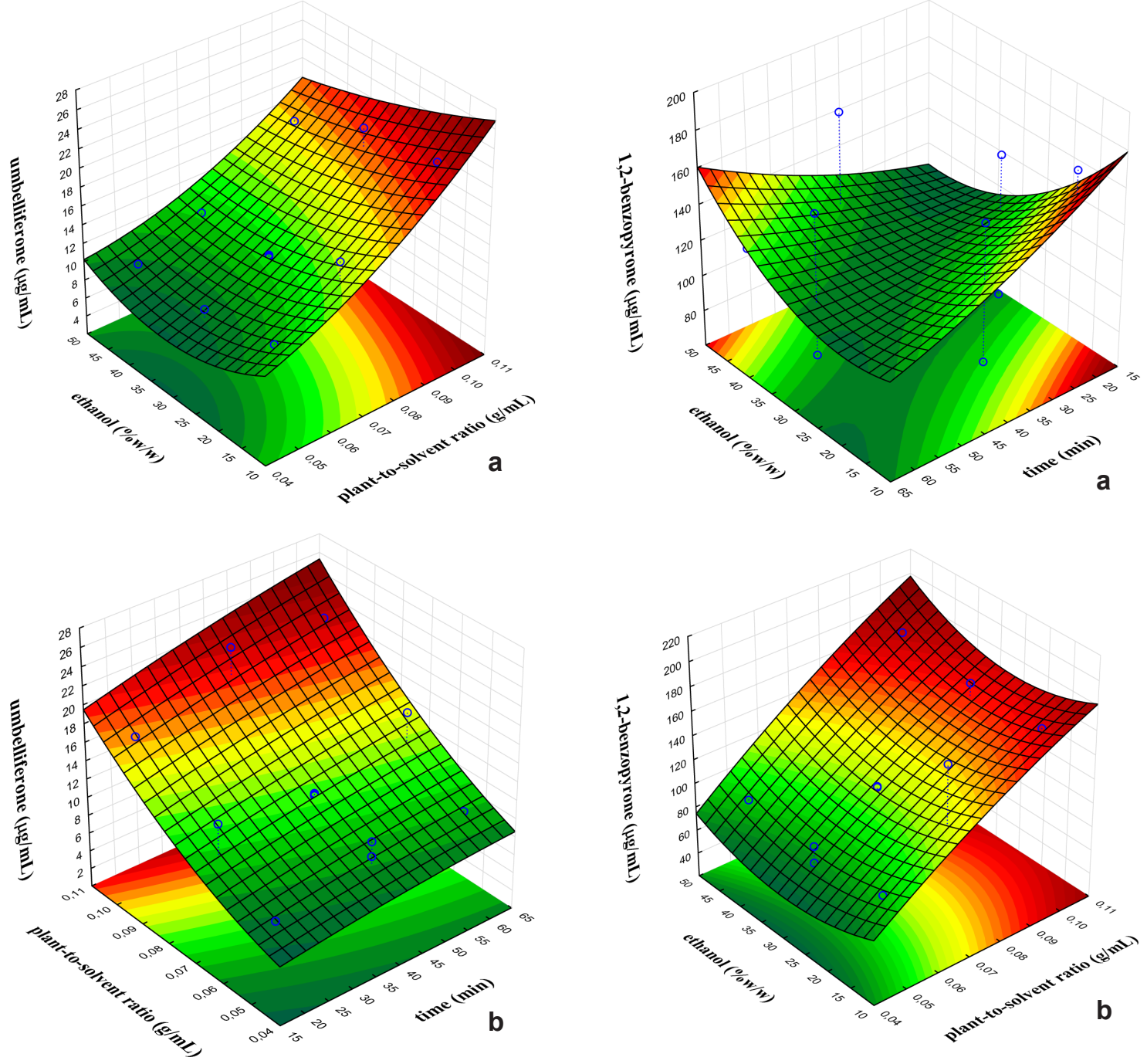

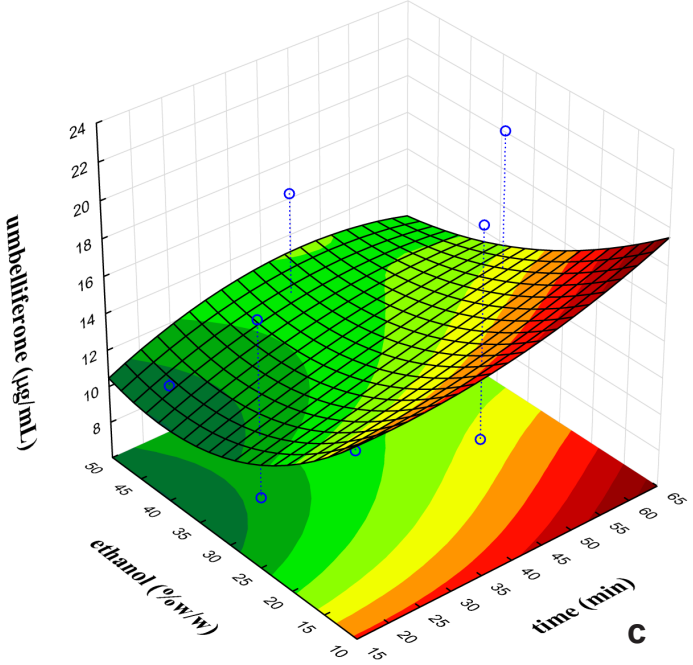

Figure 3 - a-c. Response surface for umbelliferone content from UAE experiments on $J$. pectoralis.

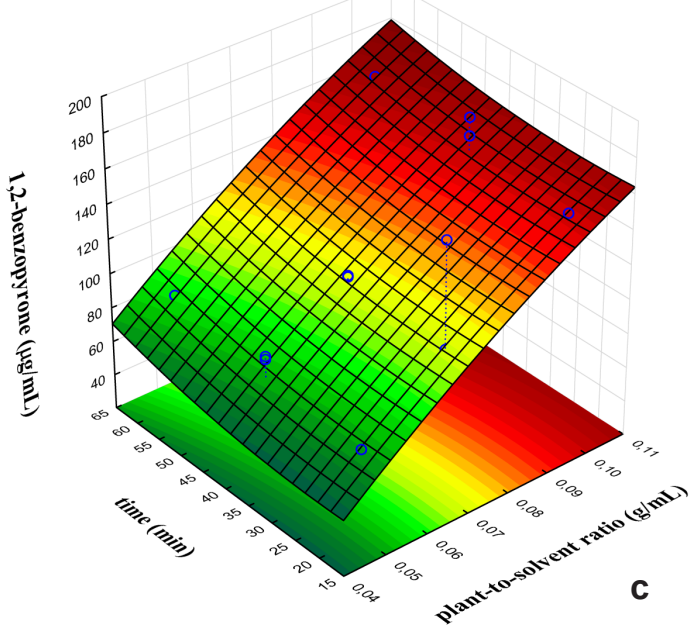

Figure 4 -a-c. Response surface for 1,2-benzopyrone content from UAE experiments on $J$. pectoralis. 
plant-to-solvent $\left(x_{3}\right)$ ratios between 0.07 and $0.1 \mathrm{~g}$ $\mathrm{mL}^{-1}$, to any of the ethanol concentrations $\left(x_{1}\right)$ and times $\left(x_{2}\right)$ of the experiment, similar results were showed by Fonseca et al. (2010), confirming that the parameter plant-to-solvent ratio $\left(x_{3}\right)$ as the most dominant factor influencing 1,2-benzopyrone and umbelliferone extraction.

Analyzed in the response surface graphs (Figs. 3a-b; 4b-c), we verified that the maximum point for the parameter plant-to-solvent ratio $\left(x_{3}\right)$ is outside the experimental area. In these cases, increased levels should be used in new experimental designs to obtain the optimal value. However, this is not feasible experimentally, due to the high intumescence of the plant material, the same limitation was observed by Xinsheng et al. (2018).

Figure 5 shows the correlation between the data predicted by the model and the experimental data observed, showing high correlation between both.

The best conditions for UAE of coumarins from aerial parts of $J$. pectoralis in the investigated ranges and obtained from the RSM general optimization function were ethanol concentration of $15 \%(\mathrm{w} / \mathrm{w})$, extraction time of $34 \mathrm{~min}$, and plant-to-solvent ratio of $0.1 \mathrm{~g} / \mathrm{mL}$. Under these conditions, the value predicted for 1,2-benzopyrone content was $163.86 \mu \mathrm{g} / \mathrm{mL}$ and $22.16 \mu \mathrm{g} / \mathrm{mL}$ for umbelliferone. These conditions were validated in independent experiments conducted in triplicate, obtaining an average of 1,2-benzopyrone content of $169.36 \mu \mathrm{g} / \mathrm{mL}$ and $19.77 \mu \mathrm{g} / \mathrm{mL}$ for umbelliferone content. This corresponds to $103.3 \%$ of the predicted value for 1,2-benzopyrone and $89.2 \%$ for umbelliferone, showing the validity of the model in predicting the phenomenon studied.

The coumarin contents for samples obtained by exhaustive percolation of plant material were $166.78 \mu \mathrm{g} / \mathrm{mL}$ for 1,2-benzopyrone and $16.27 \mu \mathrm{g} / \mathrm{mL}$ for umbelliferone. Others studies demonstrated good extraction yields for coumarins from $J$. pectoralis in hydroalcoholic solution with low ethanol content $(30 \%)$, but did not define the best ethanol concentration (Chanfrau et al. 2016); comparative studies showed the highest yields were obtained using ethanol $50 \%$ as the solvent (maceration) front of the ethanol $95 \%$ and supercritical $\mathrm{CO}_{2}$ extraction (Molnar et al. 2017). The greater efficiency of the UAE was confirmed, showing that is an eco-friendly process because the solvent used is minimal $(<25 \mathrm{~mL} /$ sample $)$,
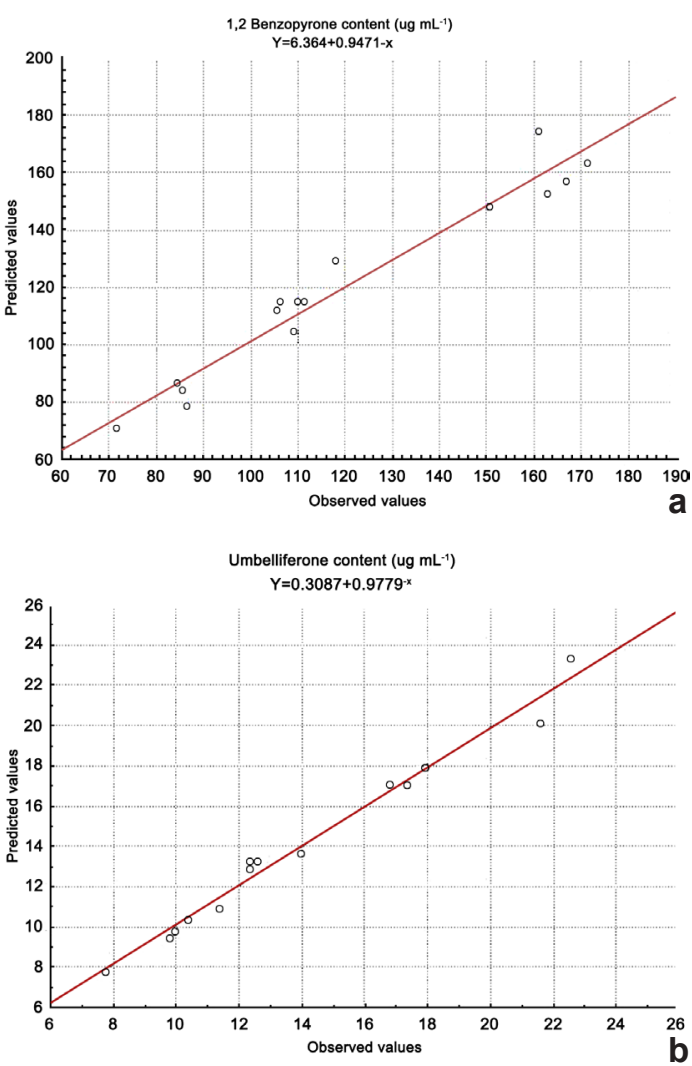

Figure 5 - $a-b$. Correlation between experimental values (observed values) and predicted values, and predictive equation, estimated using statistical model - a. for the 1,2-benzopyrone content; b. for the umbelliferone content.

with little energy cost in a short time. Therefore, as verified in other studies (Paula et al. 2016) UAE can be safely used as an inexpensive and simple extractive method.

\section{Acknowledgments}

The authors would like to express their gratitude to the Garden of Medicinal Plants of Goiânia Botanic Garden for plant supply and the State University of Goiás for financial support.

\section{References}

Angonese MT, Moreira DL \& Kaplan MAC (1992) Perfil químico da família Acanthaceae. Boletim do Museu de Biologia 1: 4-6.

Arcanjo DDR, Albuquerque ACM, Melo-Neto B, Santana LCLR, Medeiros MGF \& Citó AMGL (2012) Bioactivity evaluation against Artemia salina Leach of medicinal plants used in Brazilian 
Northeastern folk medicine. Brazilian Journal of Biology 72: 505-509.

Arteaga JJM, Perea EM, Varón EY, Ospina WFS, Osorio JN \& Martínez OMM (2011) Climate influence on chemical composition and antioxidant activity of Justicia pectoralis Jacq. Revista Cubana de Farmacia 45: 88-100.

Barros RFM, Andrade LHC \& Silva NH (1997) Concentração de cumarinas em folhas de Justicia pectoralis var stenophylla Leonard com diferentes colorações. Phyton 60: 141-145.

Brazil (2010) Farmacopeia brasileira. 5ª ed. Agência Nacional de Vigilância Sanitária, Brasília. 836p.

Brazil (2014) Instrução Normativa $n^{\circ} 4$ de 18 de junho de 2014. Guia de orientação para registro de Medicamento Fitoterápico e registro e notificação de Produto Tradicional Fitoterápico. Agência de Vigilância Sanitária, Brasília. 123p.

Brazil (2017) Agência Nacional de Vigilância Sanitária. Resolução RDC n 166, de 24 de julho de 2017. Dispõe sobre a validação de métodos analíticos e dá outras providências. Diário Oficial da União 141: 87-89.

Bubalo MC, Vidovic S, Redovnikovic IR \& Jokic S (2018) New perspective in extraction of plant biologically active compounds by green solvents. Food and Bioproducts Processing 109: 52-73.

Cameron C, Jacob AS, Thomas EA \& Levy AS (2015) Preliminary investigations of the anti-asthmatic properties of the aqueous extract of Justicia pectoralis (Fresh Cut). West Indian Medical Journal 64: 320-324.

Cárcel JA, Pérez JVG, Benedito J \& Mulet A (2012) Food process innovation through new technologies: use of ultrasound. Journal of Food Engineering 110: 200-207.

Chanfrau JER, López OD \& Núñez Y (2008) Obtencíon de uma matéria prima de calidad farmacêutica a partir de extractos de Justicia pectoralis Jacq., mediante secado por aspersión. Desarrollo tecnológico a partir de extracto hidroalcohólico al 30\%. Latin American Journal of Pharmacy 27: 333-338.

Chanfrau JER, Hernández ODL, Figueredo YN, Ferrada CR \& Mendoza AN (2013) Obtention of dry extract from aqueous extracts of Justicia pectoralis Jacq. (tilo). Revista Cubana de Plantas Medicinales 18: $1-7$.

Chanfrau RJE \& Rodríguez C (2014) Harvest time influences on coumarin and umbelliferone contents in extracts of Justicia pectoralis Jacq. (Tilo). Revista Cubana de Plantas Medicinales 48: 477-485.

Chanfrau RJE, Figueredo YN \& Moreno VF (2015) Stability of Tilo ${ }^{\circledR}$ tablets formulation obtained from dry extract of Justicia pectoralis Jacq. Brazilian Journal of Pharmaceutical Sciences 51: 193-202.

Chanfrau JER, Robaina-Mesa M, Rodríguez-Riera Z \& Jauregui-Haza U (2016) Ultrasound-assisted extraction of coumarin from Justicia pectoralis Jacq. Revista Mexicana de Ciencias Farmacéuticas 47: 96-103.

Chemat F, Albert-Vian M, Fabiano-Tixier AS, Strube J, Uhlenbrock L, Gunjevic V \& Cravotto G (2019) Green extraction of natural products. Origins, current status, and future challenges. Trends in Analytical Chemistry 118: 248-263.

Cheng JF, Chen M \& Wallace D (2004) Discovery and structure-activity relationship of coumarin derivatives as TNF-alpha inhibitors. Bioorganic \& Medicinal Chemistry Letters 14: 2411-2415.

Fonseca FN, Silva AH \& Leal LKAM (2010) Justicia pectoralis Jacq. Acanthaceae: preparation and characterization of the plant drug including chromatographic analysis by HPLC-PDA. Revista Brasileira de Farmacognosia 20: 871-877.

Govín ES, Hernández LF \& Figueredo DC (2003) Estudio farmacognóstico de Justicia pectoralis Jacq. var. stenophylla Leonard. Revista Cubana de Plantas Medicinales 8. Available at <http:// scielo.sld.cu/scielo.php?script $=$ sci_arttext\&pid $=\mathrm{S} 1028-47962003000300005>$. Access on 23 August 2017.

Hadad G, Emara S \& Mahmoud WMM (2009) Development and validation of a stability indicating RP-HPLC method for the determination of paracetamol with dantrolene or/and cetirizine and pseudoephedrine in two pharmaceutical dosage forms. Talanta 79: 1360-1367.

Han S, Zhou V \& Pan M (2005) Identification of coumarin derivatives as a novel class of allosteric MEK1 inhibitors. Bioorganic \& Medicinal Chemistry Letters 15: 5467-5473.

ICH - International Conference on Harmonization (2005) ICH Topic Q2 (R1) Validation of analytical procedures: text and methodology. Available at URL $<$ http://www.ich.org > . Access on 23 August 2017.

Kostova I (2005) Synthetic and natural coumarins as cytotoxic agents. Current Medicinal Chemistry - Anti-Cancer Agents 5: 29-46.

Leal LKAM, Silva AH \& Viana GSB (2017) Justicia pectoralis, a coumarin medicinal plant have potential for development of antiasthmatic drugs? Brazilian Journal of Pharmacognosy 27: 794-802.

Lino CS, Taveira ML, Viana GSB \& Matos JFA (1997) Analgesic and anti-inflammatory activities of Justicia pectoralis Jacq and its main constituents: coumarin and umbelliferone. Phytotherapy Research 11: 211-215.

Locklear TD, Huanga Y, Frasor J, Doylec BJ, Perez A, Gomez-Laurito J \& Mahady GB (2010) Estrogenic and progestagenic effects of extracts of Justicia pectoralis Jacq., an herbal medicine from Costa Rica used for the treatment of menopause and PMS. Maturitas 66: 315-322.

Macrae WD \& Towers GHN (1984) Justicia pectoralis: a study of the basis for its use as a hallucinogenic 
snuff ingredient. Journal of Ethnopharmacology 12: 93-111.

Martín-Viaña NP, Chanfrau JR, Hernández ODL, Sanabia MLG, Apan JMG, Moreno VMF \& Mendoza IAN (2011) Technological development of a sedative medicine of natural origin from Justicia pectoralis Jacq. Revista Cubana de Plantas Medicinales 16: 227-235.

Molnar M, Jerković I, Suknović D, Rajs BB, Aladić K, Šubarić D \& Jokić S (2017) Screening of six medicinal plant extracts obtained by two conventional methods and supercritical $\mathrm{CO}_{2}$ extraction targeted on coumarin content, 2,2-Diphenyl-1-picrylhydrazyl Radical Scavenging capacity and total phenols content. Molecules 22: 348.

Oliveira AFM \& Andrade LHC (2000) Caracterização Morfológica de Justicia pectoralis Jacq. e $J$. gendarussa Burm. F. (Acanthaceae). Revista Acta Amazônica 30: 569-578.

Parra AL, Yhebra RS, Sardiñas IG \& Buela LI (2001) Comparative study of the assay of Artemia salina L. and the estimate of the medium lethal dose (LD50 value) in mice, to determine oral acute Toxicity of plant extracts. Phytomedicine 8: 395-400.

Paula JAM, Brito LF, Caetano KLFN, Rodrigues MCM, Borges LL \& Conceição EC (2016) Ultrasoundassisted extraction of azadirachtin from dried entire fruits of Azadirachta indica A. Juss. (Meliaceae) and its determination by a validated HPLC-PDA method. Talanta 149: 77-84.

Paz JEW, Márquez DBM, Ávila GCGM, Cerda REB \& Aguilar CN (2015) Ultrasound-assisted extraction of polyphenols from native plants in the Mexican desert. Ultrasonics Sonochemistry 22: 474-481.

Prat D, Wells A, Hayler J, Sneddon H, McElroy CR, Abou-Shehada S \& Dunn PJ (2016) CHEM21 selection guide of classical- and less classicalsolvents. Green Chemistry 18: 288-295.

Ribani M, Bottoli CBG, Collins CH, Jardim ICSF \& Melo LFC (2004) Validação em métodos cromatográficos e eletroforéticos. Química Nova
27: 771-780.

Said KAM \& Amin MAM (2015) Overview on the Response Surface Methodology (RSM) in extraction processes. Journal of Applied Science \& Process Engineering 2: 8-17.

Thompson M, Ellison SLR, Fajgelj A, Willetts P \& Wood R (1999) Harmonized guidelines for the use of recovery information in analytical measurement (technical report). Pure and Applied Chemistry 71: 337-348.

Venâncio ET, Rocha NFM, Rios VER, Feitosa ML, Linhares MI, Melo FHC, Matias MS, Fonseca FN, Sousa FCF, Leal LKAM \& Fonteles MMF (2011) Anxiolytic-like effects of standardized extract of Justicia pectoralis (SEJP) in mice: involvement of GABA/Benzodiazepine in receptor. Phytotherapy Research 25: 444-450.

Vinatoru M (2001) An overview of the ultrasonically assisted of bioactive principles from herbs. Ultrasonics Sonochemistry 8: 303-313.

Vriest JX, Tauschers B \& Wurzel G (1988) Constituents of Justicia pectoralis Jacq. 2. Gas chromatography/ mass spectrometry of simple coumarins, 3-phenylpropionic acids and their hydroxy and methoxy derivatives. Biomedical \& Environmental Mass Spectrometry 15: 413-417.

Wang X, Wu Y, Chen G, Yue W, Liang Q \& Wu Q (2013) Optimization of ultrasound assisted extraction of phenolic compounds from Sparganii rhizoma with response surface methodology. Ultrasonics Sonochemistry 20: 846-854.

Xinsheng F, Shubo G, Zongyuan J, Mingqian H, Zhenzhen Y \& Zhenzhen W (2018) Optimization of ultrasonic-assisted simultaneous extraction of three active compounds from the fruits of Forsythia suspensa and comparison with conventional extraction methods. Molecules 23: 2115.

Zhou Y, Zheng J, Gan R, Zhou T, Xu D \& Li H (2017) Optimization of ultrasound-assisted extraction of antioxidants from the Mung bean coat. Molecules 22: 638 . 